\title{
Analysis of the species spectrum of the Diaporthe/Phomopsis complex in European soybean seeds
}

\author{
Behnoush Hosseini $^{1}$ (D) $\cdot$ Abbas El-Hasan ${ }^{1} \cdot$ Tobias Link $^{1} \cdot$ Ralf Thomas Voegele $^{1}$
}

Received: 12 September 2019 / Revised: 15 February 2020 / Accepted: 19 February 2020

(C) The Author(s) 2020

\begin{abstract}
Phytopathogenic fungal species of the Diaporthe/Phomopsis complex (DPC) are associated with three highly destructive diseases on soybean: seed decay, pod and stem blight, and stem canker. They are responsible for poor seed quality and significant yield reduction in most soybean-producing areas. Precise identification and classification of DPC species are important in understanding the epidemiology of disease and to develop effective control measures. Although cultural and morphological characteristics of DPC-associated pathogens have been described, establishing a more accurate taxonomic framework seems necessary for a revaluation of the taxonomy and phylogeny of DPC species. In this study, we focused on morphological and molecular analyses of species from DPC-damaged European soybean seeds obtained from several locations throughout Europe. Colony characteristics, conidia dimensions, existence of $\alpha$ - and $\beta$-conidia, and formation of perithecia were evaluated in order to assign the isolates to a species morphologically. Phylogenetic relationships were determined based on sequences from betatubulin (TUB), translation elongation factor 1-alpha (TEF1), and nuclear ribosomal DNA internal transcribed spacers (ITS). All isolates were tested for pathogenicity on soybean with positive results. In this study, we present updated taxonomic data by combining morphological observations and molecular tools which placed 32 Diaporthe isolates into four DPC species: D. longicolla, D. caulivora, D. eres, and D. novem, which are well-known soybean pathogens.
\end{abstract}

Keywords Diaporthaceae $\cdot$ Molecular phylogeny $\cdot$ Morphological characteristics $\cdot$ Seed decay

\section{Introduction}

Members of the genus Diaporthe and its anamorph Phomopsis have long been recognized as pathogens responsible for several deleterious diseases of enormous economic importance on a wide spectrum of host plants worldwide. Diaporthe species have been intensively studied, particularly those associated with soybean (Hobbs et al. 1985; Zhang et al. 1998; Santos et al. 2011), sunflower (Thompson et al. 2011), citrus (Udayanga et al. 2014a), and grapes (van Niekerk et al. 2005; Baumgartner et al. 2013). Diaporthe spp. causing diseases on soybean were initially described in the USA (Lehman 1923).

Section Editor: Marc Stadler

Behnoush Hosseini

Behnoush.Hosseini@uni-hohenheim.de

1 Department of Phytopathology, Institute of Phytomedicine (360), Faculty of Agricultural Sciences, University of Hohenheim, Otto-Sander-Str. 5, 70599 Stuttgart, Germany
Later, their occurrence has also been documented in Serbia (Nevena et al. 1997), Argentina (Pioli et al. 2001), Croatia (Santos et al. 2011), Brazil (Costamilan et al. 2008), and several other countries (Sun et al. 2013; Mengistu et al. 2014).

On soybean, Diaporthe species cause seed decay, stem blight, and stem canker leading to considerable yield losses, both quantitatively and qualitatively (Baird et al. 2001). Phomopsis seed decay (PSD) has been described as one of the most destructive diseases on soybean (Sinclair 1993). The seedborne pathogen D. longicolla is considered the main causal agent of PSD, but other DPC species have also been found to be involved in PSD. Santos et al. (2011) and Rossman et al. (2015) proposed that $D$. longicolla is synonymous to $P$. longicolla and as the older generic name should have priority. Therefore, in this manuscript, we also use Diaporthe except where we mention common names of diseases. On the other hand, $D$. longicolla was isolated from soybean stems and pods as well (Zhang et al. 1998). Infected seeds may not show clear disease symptoms, but normally are smaller than healthy seeds, shriveled, and elongated. Seed coats are often broken and covered with grayish-white mycelium (Sinclair 1992). This affects the quality of seeds by 
Table 1 DPC species isolated from European soybean seeds

\begin{tabular}{|c|c|c|c|c|c|c|}
\hline \multirow[t]{2}{*}{ Species } & \multirow[t]{2}{*}{ Isolate no. } & \multirow[t]{2}{*}{ Cultivar } & \multirow[t]{2}{*}{ Origin } & \multicolumn{3}{|c|}{ GenBank accessions } \\
\hline & & & & ITS & TEF1 & $T U B$ \\
\hline \multirow[t]{21}{*}{ D. longicolla } & DPC_HOH1 & Sigalia & Austria & MK024676 & MK099093 & MK161475 \\
\hline & DPC_HOH5 & CH 22232 & Austria & MK024680 & MK099097 & MK161479 \\
\hline & DPC_HOH6 & Gallec & Austria & MK024681 & MK099098 & MK161480 \\
\hline & DPC_HOH9 & Korus & Austria & MK024684 & MK099101 & MK161483 \\
\hline & DPC_HOH12 & Silvia PZO & Austria & MK024687 & MK099104 & MK161486 \\
\hline & DPC_HOH13 & Gallec & Austria & MK024688 & MK099105 & MK161487 \\
\hline & DPC_HOH17 & Sigalia & Austria & MK024692 & MK099109 & MK161491 \\
\hline & DPC_HOH18 & Primus & Austria & MK024693 & MK099110 & MK161492 \\
\hline & DPC_HOH19 & Primus & Austria & MK024694 & MK099111 & MK161493 \\
\hline & DPC_HOH20 & Silvia PZO & Austria & MK024695 & MK099112 & MK161494 \\
\hline & DPC_HOH21 & Gallec & Austria & MK024696 & MK099113 & MK161495 \\
\hline & DPC_HOH22 & Sultana & Germany & MK024697 & MK099114 & MK161496 \\
\hline & DPC_HOH23 & Sultana & Germany & MK024698 & MK099115 & MK161497 \\
\hline & DPC_HOH24 & Sultana & Germany & MK024699 & MK099116 & MK161498 \\
\hline & DPC_HOH25 & Merlin & Austria & MK024700 & MK099117 & MK161499 \\
\hline & DPC_HOH26 & Gallec & Austria & MK024701 & MK099118 & MK161500 \\
\hline & DPC_HOH28 & Malaga & Austria & MK024703 & MK099120 & MK161502 \\
\hline & DPC_HOH29 & Gallec & Austria & MK024704 & MK099121 & MK161503 \\
\hline & DPC_HOH30 & Silvia PZO & Austria & MK024705 & MK099122 & MK161504 \\
\hline & DPC_HOH31 & Merlin & Austria & MK024706 & MK099123 & MK161505 \\
\hline & DPC_HOH32 & CH 22177 & Austria & MK024707 & MK099124 & MK161506 \\
\hline \multirow[t]{2}{*}{ D. caulivora } & DPC_HOH2 & Primus & Austria & MK024677 & MK099094 & MK161476 \\
\hline & DPC_HOH4 & Primus & Austria & MK024679 & MK099096 & MK161478 \\
\hline \multirow[t]{5}{*}{ D. eres } & DPC_HOH3 & CH 22177 & Austria & MK024678 & MK099095 & MK161477 \\
\hline & DPC_HOH7 & Amadine & Austria & MK024682 & MK099099 & MK161481 \\
\hline & DPC_HOH10 & Silvia PZO & Austria & MK024685 & MK099102 & MK161484 \\
\hline & DPC_HOH14 & Primus & Austria & MK024689 & MK099106 & MK161488 \\
\hline & DPC_HOH27 & Sigalia & Austria & MK024702 & MK099119 & MK161501 \\
\hline \multirow[t]{4}{*}{ D. novem } & DPC_HOH8 & Sultana & Austria & MK024683 & MK099100 & MK161482 \\
\hline & DPC_HOH11 & Pollux & France & MK024686 & MK099103 & MK161485 \\
\hline & DPC_HOH15 & Pollux & France & MK024690 & MK099107 & MK161489 \\
\hline & DPC_HOH16 & Sigalia & Austria & MK024691 & MK099108 & MK161490 \\
\hline
\end{tabular}

reducing oil and protein contents, quality of flour, and seed germination (Sinclair 1993). Warm and moist weather conditions, especially during pod filling and maturation, promote pathogen growth and disease development (Sinclair 1993).

Morphological differentiation among DPC species has been based on multifarious criteria including colony appearance, presence of an anamorph/teleomorph, presence of $\alpha$-conidia and/or $\beta$-conidia (Morgen-Jones 1985), disease symptoms, and aggressiveness on soybean (Sinclair and Backman 1989). Due to a high degree of variability in morphology, physiology, and host relationships among species of DPC, classification at the species level is considered unsatisfactory (Morgan-Jones 1989). For decades, DPC species were mostly defined according to the host but later it was noticed that host range is not useful for the taxonomy of these species (Mostert et al. 2001). Similarly, morphological characteristics are not appropriate for differentiation of these fungi at species level due to their variability under different environmental conditions (van der Aa et al. 1990). Recently, attention has been given to a revaluation of the taxonomy using nucleic acid sequence data to clarify existing conflicts. In several reports, multi-locus phylogenies were used for accurate species differentiation within the genus Diaporthe (van Rensburg et al. 2006; Udayanga et al. 2012). Hence, this study aimed to isolate and identify Diaporthe species associated with soybean seeds obtained from different regions in Austria, France, and Germany using classical and molecular techniques. Here, we present the species associated with European soybean seeds with an updated version of species descriptions and sequence 
Table 2 Highly homologous isolates to the DPC species isolated from European soybean seeds (ex-type strains in bold)

\begin{tabular}{lll}
\hline Target region & Species & GenBank accessions \\
\hline ITS & D. longicolla & HQ333500, HQ333502, HQ333504, HM347700 (CBS 127267) \\
& D. eres & KC343074, KC343075, KJ210516, DQ491514, KJ210518, JF430487, JF430493, MG281083 \\
& (CPC 3011), MG281047 (CPC 29825), MG281103 (CPC 30135), MG281099 (CPC 30131) \\
& D. caulivora & KC343046, JF418936, JF418934, EU622854, HM625752, HM347712 (CBS 127268) \\
D. novem & KC343155, KC343157, GQ250225, DQ286285, JQ697841, JQ697843, JF704181, HM347710 \\
& (CBS 127271), HM347708 (CBS 127269), HM347709 (CBS 127270) \\
& D. longicolla & AF398896, HM347685 (CBS 127267) \\
DEF1 eres & KC343801, KJ210553, KJ210540, KJ210541, KJ210551, KJ210549, JF461473, MG281604 \\
& (CPC 30111), MG281568 (CPC 29825), MG281624 (CPC 30135), MG281620 (CPC 30131) \\
& D. caulivora & JF461465, HM347691 (CBS 127268) \\
& D. novem & KC343881, HM347697, DQ286259, GQ250363, JQ697854, JQ697856, JF704182, HM347693 \\
& (CBS 127269), HM347695 (CBS 127271), HM347696 (CBS 127270) \\
D. longicolla & HQ333510 (strain SSLP-1), HQ333512 (strain SSLP-3) \\
D. eres & KJ420823, KJ420810, KJ420785, KJ420822, KJ420800, KJ420783, MG281256 (CPC 30111), \\
& MG281220 (CPC 29825), MG281276 (CPC 30135), MG281272 (CPC 30131) \\
& D. caulivora & HQ333513, KC344013 (CBS 127268) \\
D. novem & KC344123 (CBS 127269), KC344125 (CBS 127271)
\end{tabular}

information that should considerably facilitate identification of $\mathrm{DPC}$ species in the future.

\section{Materials and methods}

\section{Seed sampling, isolation, and morphological characterization of fungi}

Soybean seeds obtained from various locations in Austria, France, and Germany were kindly provided by Taifun-Tofu GmbH (Freiburg, Germany) (Table 1). Fungal pathogens were isolated from seeds using the method described by Walcott (2014) with some modifications. Briefly, seeds were rinsed in $1 \%$ sodium hypochlorite solution for $30 \mathrm{~s}$, followed by washing with sterile distilled water, drying on filter paper and then culturing on acidified potato dextrose agar (APDA; $\mathrm{pH}=4.5$ ). Plates were sealed with Parafilm and incubated at $24{ }^{\circ} \mathrm{C}$ under a 12-h light/dark regime. Developing mycelia of each putative DPC species were transferred to fresh APDA plates and incubated under the same conditions for 30 days. Then suspensions of $\alpha$-conidia and/or $\beta$-conidia of each Diaporthe isolate were used to produce single-spore isolates using the method described by Choi et al. (1999).

The purified Diaporthe isolates were identified based on morphological characteristics including colony appearance. Colony color (front and back) was scored according to the color chart described by Rayner (1970). Existence of pycnidia including conidiophores with $\alpha$-conidia and $\beta$-conidia, dimensions of conidia and the presence of perithecia with asci and ascospores on APDA or autoclaved soybean stems were observed using either a Stemi 2000 binocular loupe or a Primo Star microscope (Carl Zeiss, Oberkochen, Germany).

Images were acquired using an AxioCam HRC color camera (Carl Zeiss) and evaluated with AxioVision software (Release 4.8.3 Special Edition 1).

\section{DNA extraction and PCR amplification}

Fungal genomic DNA from all Diaporthe isolates was extracted using the protocol used by Liu et al. (2000). Three genomic markers, the internal transcribed spacer (ITS) region of the nuclear ribosomal DNA, which has been proposed as the standard fungal barcode (Schoch et al. 2012), parts of the translation elongation factor 1- $\alpha(T E F 1)$ and beta-tubulin $(T U B)$, were amplified using the established primer pairs ITS1/ITS4 (White et al. 1990), EF1-728F/EF1-986R (Carbone and Kohn 1999), and Bt-2a/Bt$2 \mathrm{~b}$ (Glass and Donaldson 1995). Amplifications were performed in a $40-\mu \mathrm{L}$ reaction volume $(8 \mu \mathrm{L} 5 \times$ Phusion HF buffer (Thermo Fisher Scientific, Waltham, MA, USA), $4 \mu \mathrm{L} 2 \mathrm{mM}$ dNTPs, $24.6 \mu \mathrm{L} \mathrm{H}_{2} \mathrm{O}, 1 \mu \mathrm{L}$ of each forward and reverse primers (10 pmol $/ \mu \mathrm{L}), 0.4 \mu \mathrm{L}$ Phusion DNA polymerase $(2 \mathrm{U} / \mu \mathrm{L})$, and $1 \mu \mathrm{L}$ genomic DNA). The ITS region was amplified under the following conditions: $30 \mathrm{~s}$ at $98^{\circ} \mathrm{C}, 35$ cycles: denaturation $10 \mathrm{~s}$ at $98{ }^{\circ} \mathrm{C}$, annealing $20 \mathrm{~s}$ at $54{ }^{\circ} \mathrm{C}$, and elongation $35 \mathrm{~s}$ at $72{ }^{\circ} \mathrm{C}$, and then a final step of $10 \mathrm{~min}$ at $72{ }^{\circ} \mathrm{C}$. PCR conditions for amplifying $T E F 1$ were $30 \mathrm{~s}$ at $98^{\circ} \mathrm{C}, 35$ cycles: denaturation $10 \mathrm{~s}$ at $98{ }^{\circ} \mathrm{C}$, annealing $50 \mathrm{~s}$ at $58{ }^{\circ} \mathrm{C}$, and elongation for $35 \mathrm{~s}$ at $72{ }^{\circ} \mathrm{C}$, and a final step at $72{ }^{\circ} \mathrm{C}$ for $10 \mathrm{~min}$. PCR conditions for amplifying $T U B$ were $30 \mathrm{~s}$ at $98^{\circ} \mathrm{C}, 35$ cycles: denaturation $10 \mathrm{~s}$ at $98{ }^{\circ} \mathrm{C}$, annealing $15 \mathrm{~s}$ at $60{ }^{\circ} \mathrm{C}$, and elongation for $15 \mathrm{~s}$ at $72{ }^{\circ} \mathrm{C}$, and a final step at $72{ }^{\circ} \mathrm{C}$ for $7 \mathrm{~min}$. PCR products were 
Fig. 1 Maximum likelihood phylogenetic analysis of the DPC species associated with soybean based on ITS. Bootstrap numbers represent percent of 100 replicates. For each species, the ex-type strain sequences were included by their accession numbers followed by strain names and the sequences of the Diaporthe isolates were included by their isolate number

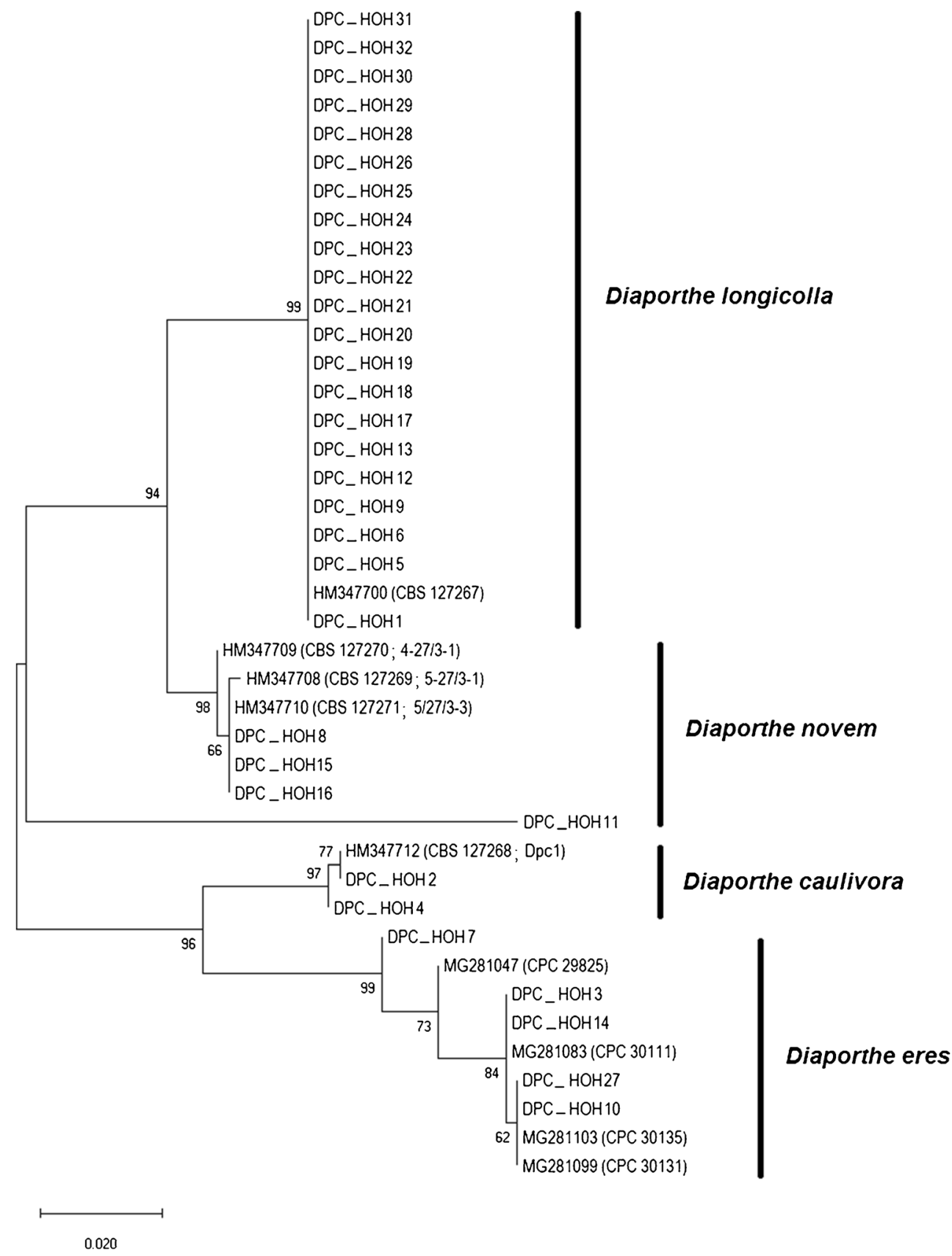

visualized by electrophoresis on $2 \%$ agarose gels after staining with $0.05 \%$ ethidium bromide.

\section{DNA sequencing and phylogenetic analysis}

PCR amplicons were purified using the PEQGOLD Cycle-Pure Kit (PEQLAB Biotechnologie GmbH, Erlangen, Germany) and sequenced with the forward and reverse primers (Source Bioscience, Berlin, Germany, and Microsynth Seqlab, Göttingen, Germany). DNA sequences were viewed and edited using GENtle v. 1.9 and Lasergene ver. 5.07 (DNASTAR, Madison, WI, USA). DNA sequences of each isolate were searched against GenBank by nucleotide BLAST, and then they were deposited in NCBI's GenBank (Table 1). Multiple sequence alignments were done using ClustalW as implemented in BioEdit (version 7.1.3.0; Hall 1999). Phylogenetic trees containing all isolates were constructed for each gene along with reference sequences from ex-type strains for each species. The reference sequences were obtained from NCBI (Table 2). In the phylogenetic trees for the ITS, TEF, and TUB genes, accession numbers of the sequences are given together with the strain names. The concatenated alignment was generated by fusing the TUB, TEF1, and ITS sequences. Phylogenetic trees were constructed for each gene and concatenated sequences using the maximum composite likelihood method (Tamura et al. 2004) in MEGA-X (Tamura and Nei 1993; Kumar et al. 2018) with default options: a robust 
Fig. 2 Maximum likelihood phylogenetic analysis of the DPC species associated with soybean based on TEF1. Bootstrap numbers represent percent of 100 replicates. For each species, the ex-type strain sequences were included by their accession numbers followed by strain names and the sequences of the Diaporthe isolates were included by their isolate number

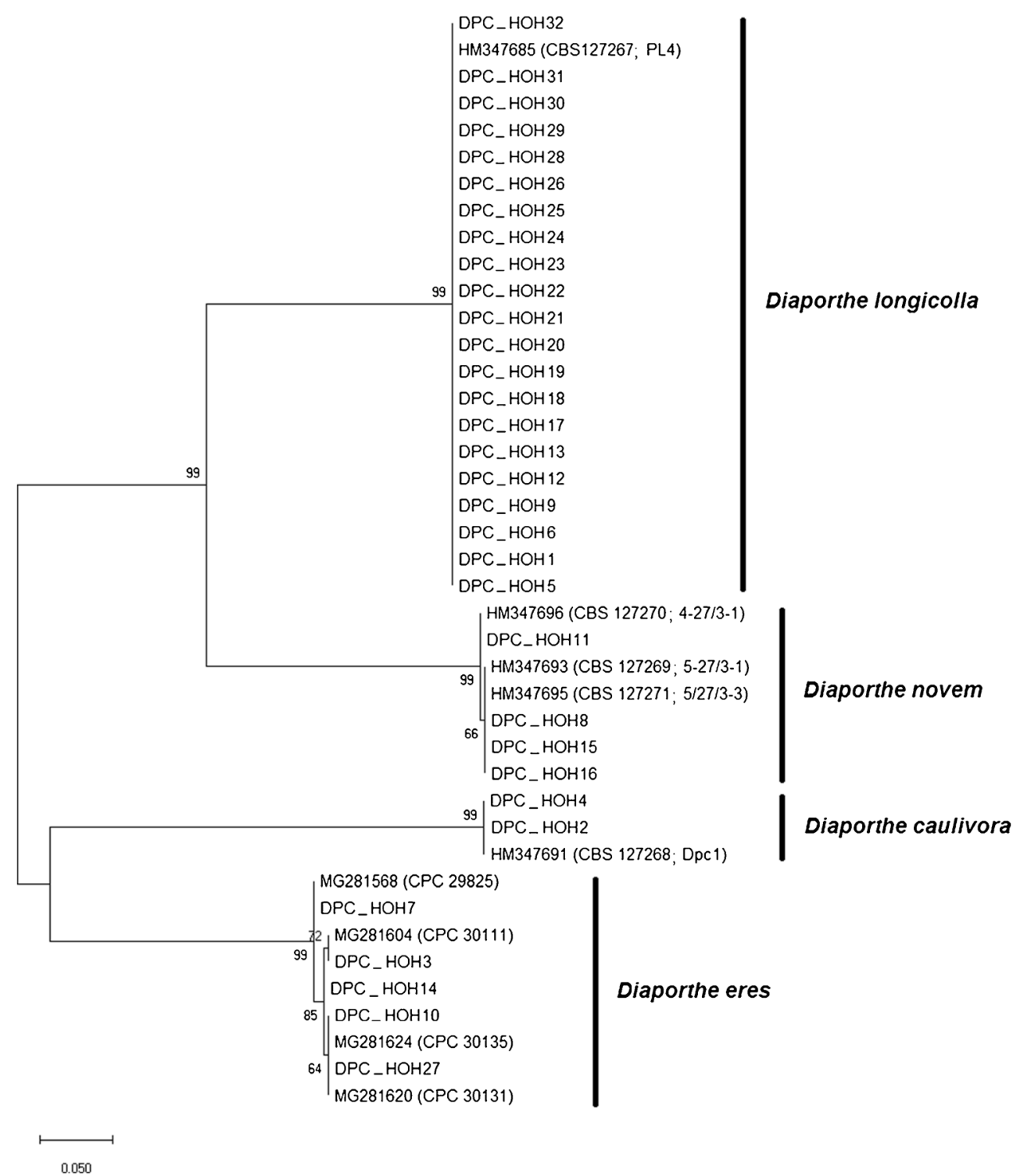

test of 100 bootstraps, Tamura-Nei Model, uniform rates, all sites, nearest neighbor interchange, initial tree by neighbor joining, no branch swap filter, and 3 threads. In the combined phylogenetic tree, the reference strains were included just by name.

\section{Pathogenicity of the Diaporthe isolates}

The pathogenicity of the isolated Diaporthe strains was evaluated by separately inoculating healthy germinated soybean seeds with conidia suspensions of all Diaporthe strains. Briefly, soybean seeds of susceptible cultivar Anushka were surface-disinfected using $0.5 \%$ sodium hypochlorite solution for $2 \mathrm{~min}$, followed by rinsing with sterile distilled water, and then incubation in humid chambers made of Petri dishes containing wet filter papers at room temperature. After 7 days, healthy germinated seeds were selected for inoculation. For each of the Diaporthe isolates, nine germinated seeds were inoculated by soaking in $50-\mathrm{mL}$ conidia suspensions $(4.405 \times$ $10^{4}$ spores $/ \mathrm{mL}, 0.5 \%$ tween 20 , and $0.5 \%$ carboxymethylcellulose (CMC) in Erlenmeyer flasks for $30 \mathrm{~min}$ at room temperature. Respective control treatments were set up. After inoculation, three seeds were transferred into each pot $(12 \mathrm{~L})$ containing a mixture of $50 \%$ seedling substrate (Klasmann-Deilmann $\mathrm{GmbH}$ ) and $50 \%$ soil (Gebr. Patzer $\mathrm{GmbH})$. The pots were arranged in a randomized complete block design in the greenhouse at $28{ }^{\circ} \mathrm{C}$ under a light/dark cycle of $16 / 8 \mathrm{~h}$.

Symptoms of stem and pot blight disease on each plant were first graded after 3 months and then for three more times, 1, 2, and 3 weeks later. Stem blight symptoms were graded along a 4point disease severity scale: $0=$ no symptoms, $1=<25 \%$ of the stem covered with pycnidia, $2=26-50 \%$ infected area, $3=51$ $75 \%$ infected area, and $4=76-100 \%$ almost fungal structures on the whole stem. Pod blight symptoms were graded along a 3point disease severity scale including as follows: $0=$ no changing 


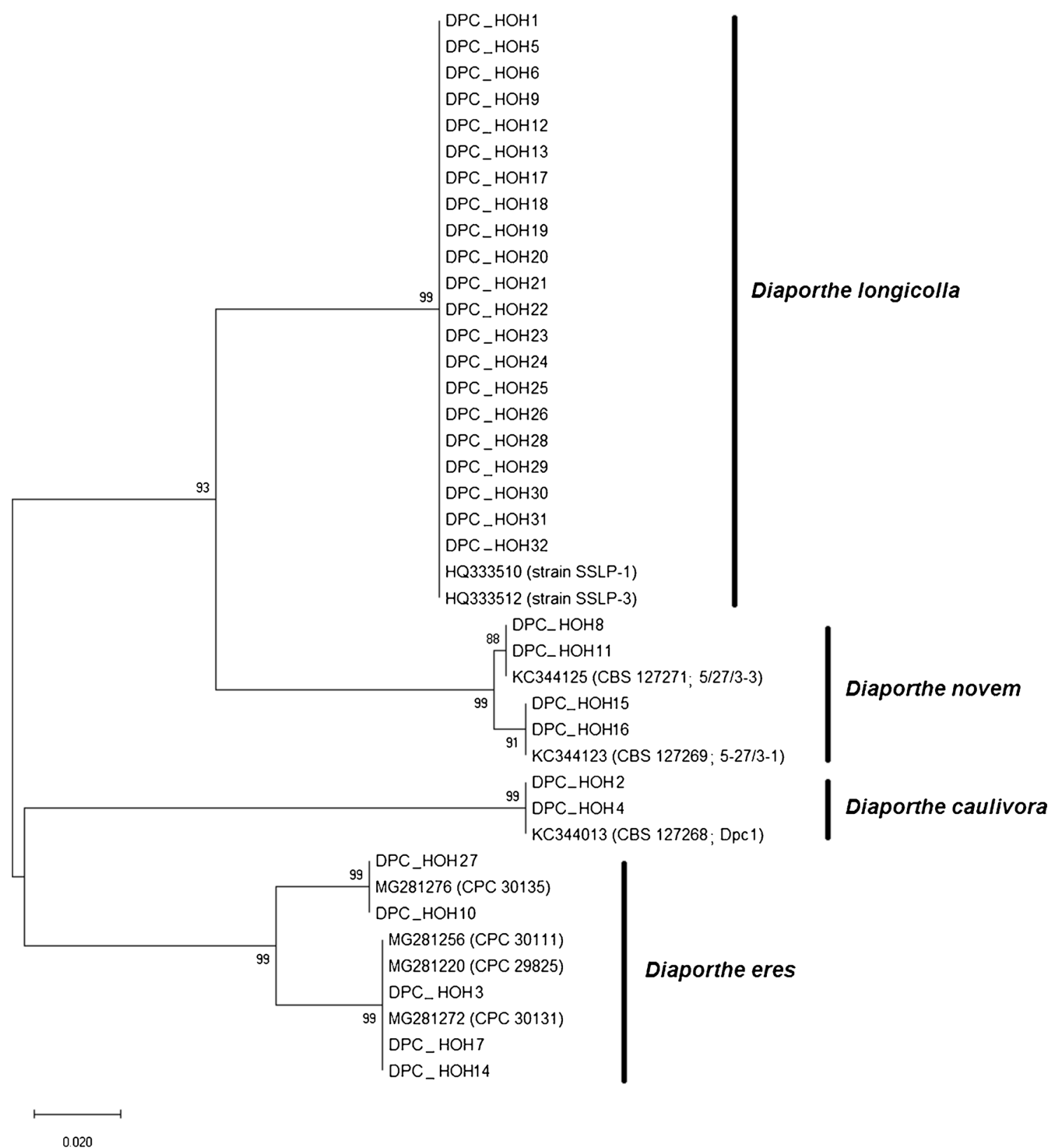

Fig. 3 Maximum likelihood phylogenetic analysis of the DPC species associated with soybean based on TUB. Bootstrap numbers represent percent of 100 replicates. For each species, the ex-type strain sequences

color, $0.5=$ less than $50 \%$ appearance of brownish color areas on pods, and $1=>50 \%$ brownish color areas on pods.

\section{Results}

\section{Identification of Diaporthe species based on morphological characteristics and TUB, TEF1, and ITS sequences}

In order to determine the occurrence of DPC species in central Europe, soybean seeds were collected from different regions were included by their accession numbers followed by strain names and the sequences of the Diaporthe isolates were included by their isolate number

and after surface disinfection, they were cultured on APDA for 30 days. In addition to other fungal pathogens like Fusarium spp. and Alternaria spp., these samples yielded 32 Diaporthe isolates. The latter were purified using the singlespore method and were preserved on APDA plates at $10^{\circ} \mathrm{C}$ in the Institute of Phytomedicine at the University of Hohenheim. The 32 Diaporthe isolates were initially evaluated based on their morphological characteristics including formation of sexual or asexual structures, size and type of conidia and conidiophores, and colony appearance. However, due to the high variability in morphological features, determining the species was challenging for some isolates (e.g., DPC HOH18 


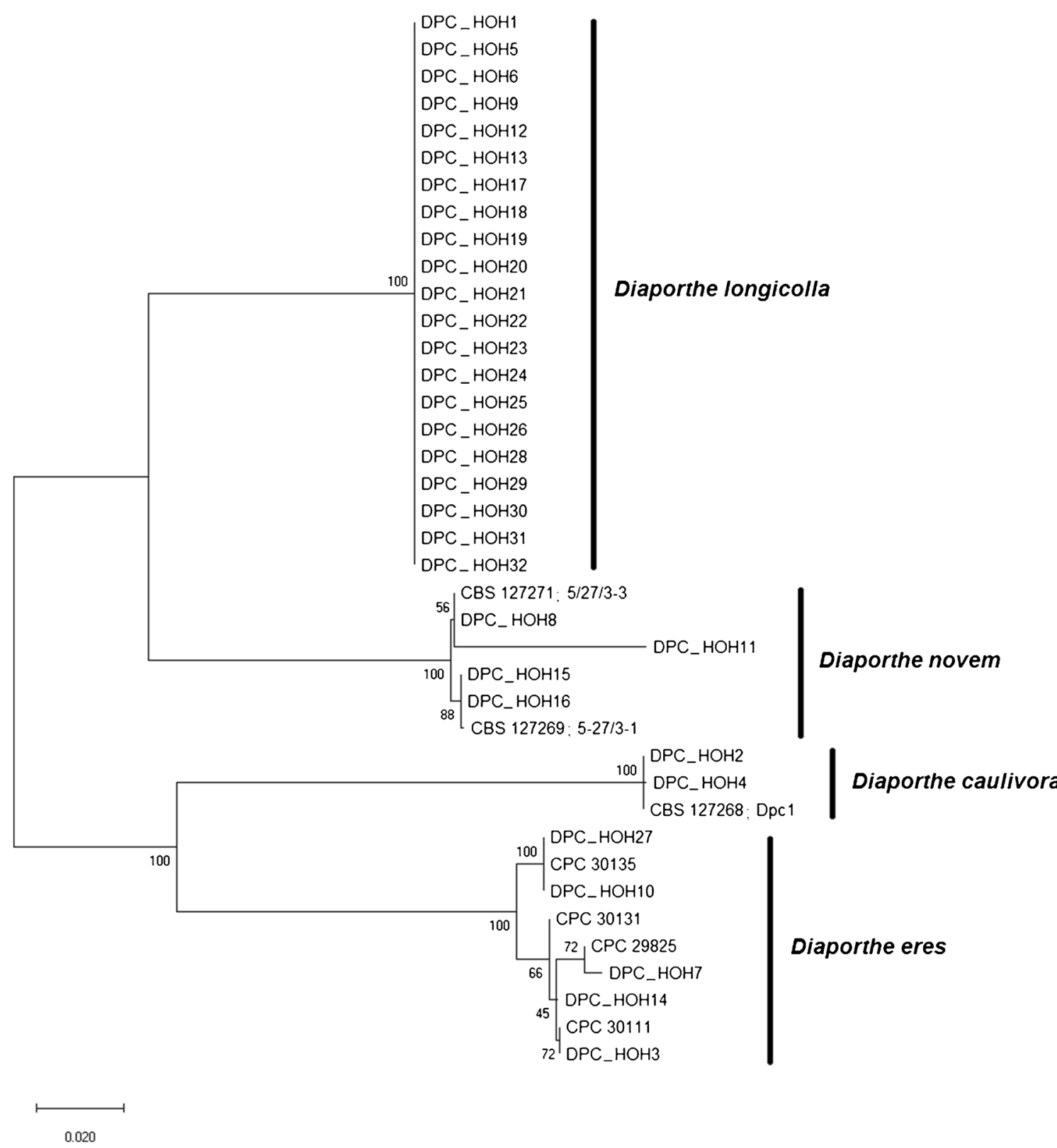

Fig. 4 Maximum likelihood phylogenetic analysis of the DPC species associated with soybean based on the combined three-gene sequence alignment (TUB, TEF1, and ITS). Bootstrap numbers represent percent of 100 replicates. For each species, the ex-type strain sequences were

included by their strain names. The sequences of the Diaporthe isolates were included by their isolate number. No type strain for which all three sequences were available could be identified for $D$. longicolla

and DPC_HOH21). Therefore, we tried to confirm the morphological grouping with molecular tools in order to gain sufficient delineation of the different Diaporthe species. DNA of the 32 Diaporthe isolates was prepared for ITS sequencing. However, identification of fungi solely based on ITS sequences is also not entirely reliable due to a lack of database entries and some incorrect species annotations. Hence, the sequences of $T U B$ and TEF 1 loci were employed as well. All three molecular markers were successfully amplified and sequenced from the 32 Diaporthe isolates.
Phylogenetic analyses of the three marker sequences demonstrated largely congruent groupings of almost all isolates (Figs. 1, 2, and 3).

Finally, based on morphological identification and phylogenetic trees created from the results of BLAST analyses using ITS, TEF1, and TUB sequences, the 32 Diaporthe isolates could be classified into four species (Fig. 4). Accordingly, 21 isolates (DPC_HOH1, DPC_HOH5, DPC_HOH6, DPC_HOH9, DPC_HOH12, DPC_HOH13, DPC_HOH17, DPC_HOH18, DPC_HOH19, DPC_HOH20, DPC_HOH21, 

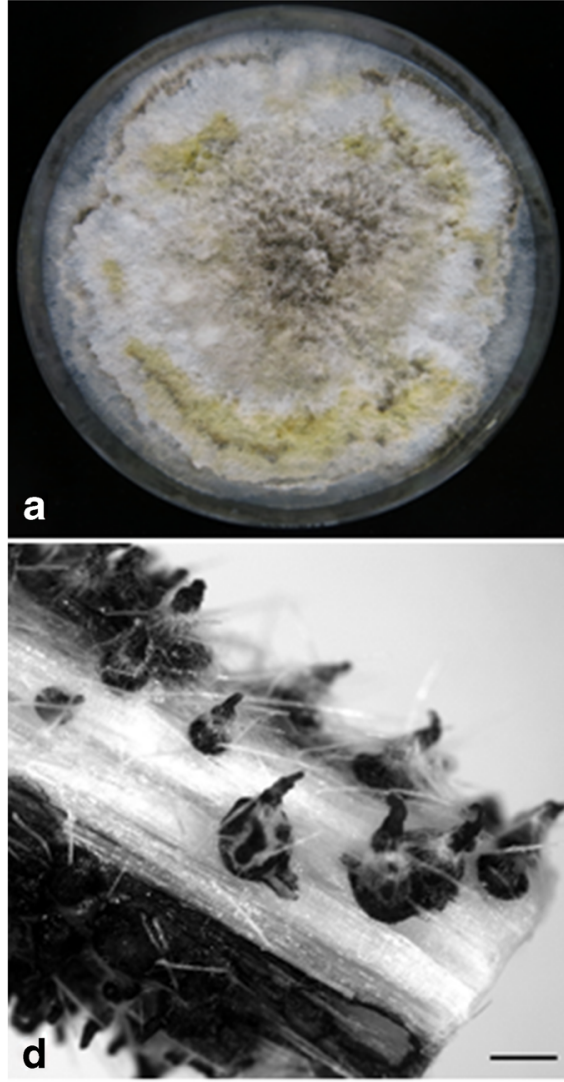

\section{b}
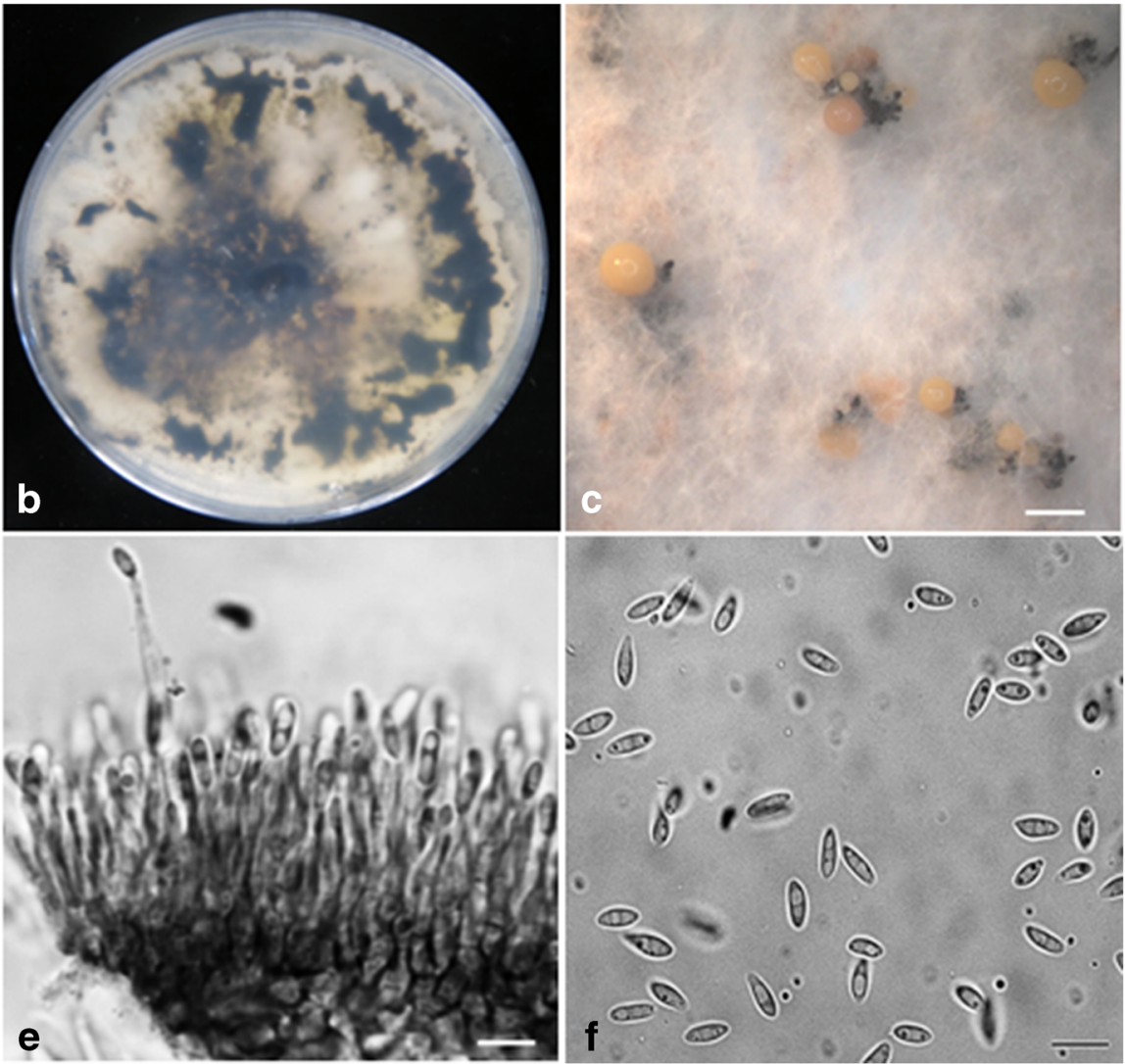

soybean stem in culture. e Conidiogenous cells and conidiophores. $\mathbf{f} \alpha$ conidia. Scale bars $(\mathbf{c}, \mathbf{d}) 500 \mu \mathrm{m},(\mathbf{e}, \mathbf{f}) 10 \mu \mathrm{m}$

a Surface view of the cultures on APDA after 1 month. b Backside view of the cultures. c Conidiomata sporulating on APDA. d Pycnidia on

DPC_HOH22, DPC_HOH23, DPC_HOH24, DPC_HOH25, DPC_HOH26, DPC_HOH28, DPC_HOH29, DPC_HOH30, DPC_HOH31, and DPC_HOH32) were assigned to $D$. longicolla, which, therefore, was the dominant Diaporthe species in this study. It was isolated from seedlots obtained from different regions in Austria and Germany. Morphologically, all $D$. longicolla isolates conform to the description of Hobbs et al. (1985) except for DPC_HOH18 and DPC_HOH21, which were growing significantly slower and both by this phenomenon and by colony appearance, especially color and shape, were similar to isolate IL12-Ds-2 described by Divilov (2014).

Isolates DPC_HOH3, DPC_HOH7, DPC_HOH10, DPC $\mathrm{HOH} 14$, and DPC $\mathrm{HOH} 27$ were grouped as D. eres. Isolates DPC $\mathrm{HOH} 2$ and DPC $\mathrm{HOH} 4$ were classified as $D$. caulivora. D. eres and D. caulivora isolates only came from Austrian soybean seedlots. D. eres isolates were identified based on the original description given by Nitschke (1870) and $D$. caulivora based on the description given by Athow and Caldwell (1954) and Kulik (1984).

Isolates DPC HOH8, DPC HOH11, DPC HOH15, and $\mathrm{DPC} \mathrm{HOH} 16$ were identified as $D$. novem and were isolated from soybean seeds collected from France and Austria.

\section{Taxonomy}

All descriptions provided are based on morphological differentiation among the four Diaporthe species and their molecular classification in the phylogenetic trees.

Diaporthe longicolla (Hobbs) J.M. Santos, Vrandečić \& A.J.L. Phillips, Persoonia 27: 13 (2011).

Phomopsis longicolla Hobbs, Mycologia 77: 542 (1985).

Sequences from ex-type strains: ITS: HM347700, TEF1: HM347685, and TUB: HQ333510, HQ333512.

For most of our isolates, fluffy and dense aerial mycelium of $D$. longicolla in white colonies with greenish yellow areas appeared on APDA (Fig. 5a). From the reverse side, colony color appeared initially greenish, yellow and black spots developed later (Fig. 5b). D. longicolla reproduced asexually with $\alpha$-conidia, while $\beta$-conidia were absent. This species differs from $D$. novem (in this study) in generating enormous stromata with long pycnidial beaks on APDA and soybean stems in culture (Fig. $5 \mathrm{c}, \mathrm{d})$ containing oval shaped, hyaline and biguttulate $\alpha$ conidia (5.5-7.4 × 2.0-2.4 $\mu \mathrm{m})$ exuding from the pycnidial ostiole in a yellowish, creamy drop (Fig. $5 f$ ), as well as in producing smaller and wider $\alpha$-conidia. 

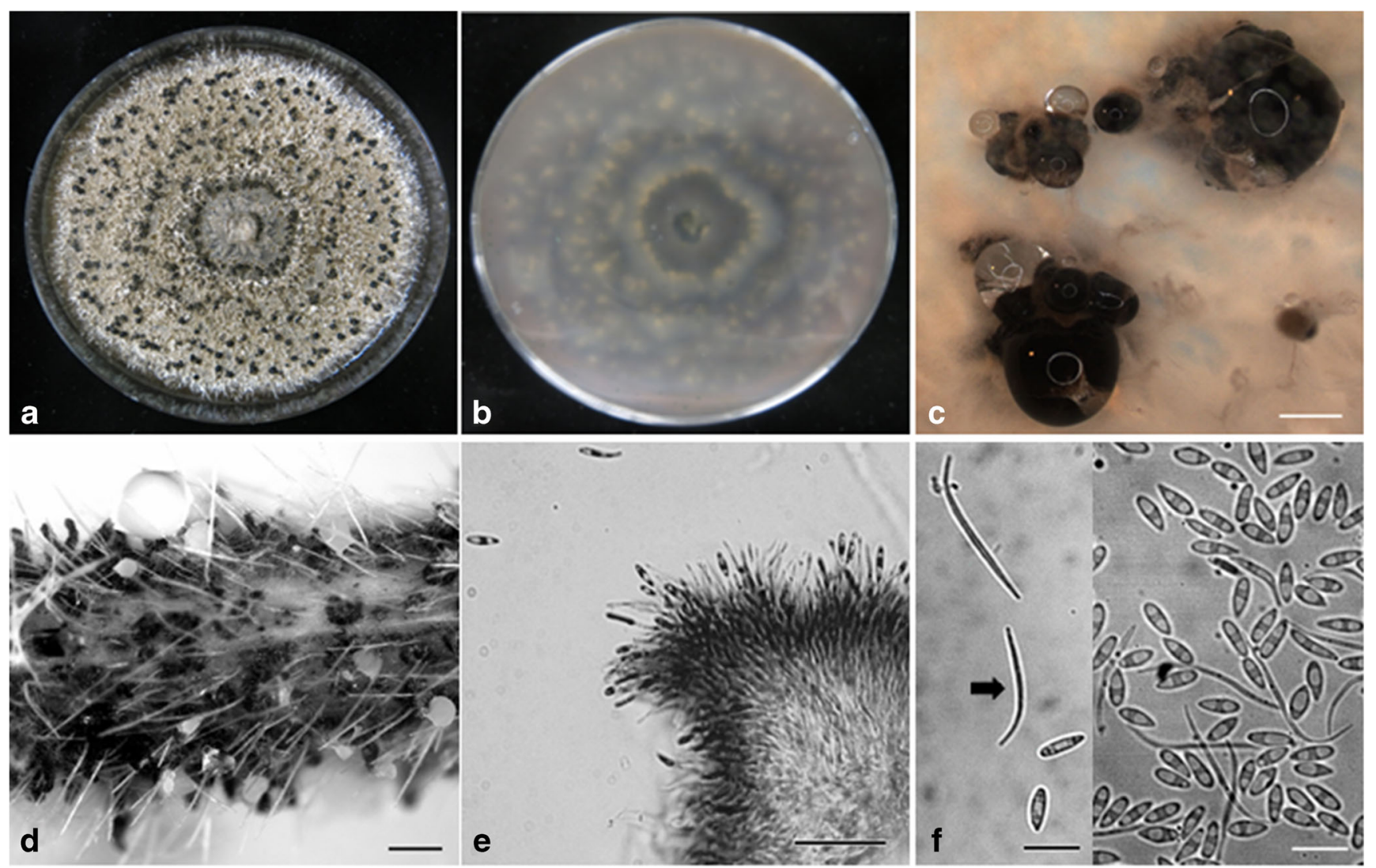

Fig. 6 Macro- and micrographs of D. eres (isolate DPC_HOH3). a Surface view of the cultures on APDA after 1 month. b Backside view of the cultures. c Conidiomata sporulating on APDA after 2 months. d
Pycnidia on soybean stem in culture. e Conidiogenous cells and conidiophores. f $\alpha$-conidia and $\beta$-conidia (arrow). Scale bars (c) $200 \mu \mathrm{m}$, (d) $500 \mu \mathrm{m}$, (e) $20 \mu \mathrm{m}$, (f) $10 \mu \mathrm{m}$
Isolates DPC_HOH18 and DPC_HOH21 grew relatively slower than the other $D$. longicolla isolates. Both isolates produced floccose grayish to brownish mycelia on APDA. The colonies showed grayish color on the reverse side of the dish. DPC_HOH18 and DPC_HOH21 reproduced asexually and pycnidia with a very little short beak or none formed on soybean stems. The pycnidia contained hyaline and usually fusiform, guttulate $\alpha$-conidia with 5.3-8.5 $\times 2.6-4.1 \mu \mathrm{m}$ diam.

BLAST analyses using TEF1, ITS, and TUB sequences of the isolates identified morphologically as $D$. longicolla showed a high degree of homology (99-100\%) to the sequences (Table 2) from $D$. longicolla isolates isolated from soybean in Korea and Serbia. All D. longicolla isolates were identical in sequence for all three genetic markers (Figs. 1, 2, 3, and 4).

Diaporthe eres Nitschke, Pyrenomycetes Germanici 2: 245 (1870).

Sequences from ex-type strains: ITS: MG281083, MG281047, MG281103, MG281099, TEF1: MG281604, MG281568, MG281624, MG281620, and TUB: MG281256, MG281220, MG281276, MG281272.

Aerial fluffy mycelia of $D$. eres (isolates DPC_HOH3, DPC HOH7, DPC HOH10, DPC $\mathrm{HOH}_{14}$, and DPC_HOH27) appeared white in color with emerging dark pigmentation spots along with production of enormous black stromata (Fig. 6a). The colony color on the reverse side was gray (Fig. 6b). These isolates reproduced asexually and pycnidia released a spore bulk containing $\alpha$-conidia and $\beta$ conidia (Fig. 6c, d) and due to production of both types of conidia, this species could be distinguished from $D$. longicolla and $D$. novem. $\alpha$-Conidia were oval and measured 5.7-8.2 $\times$ $1.3-2.5 \mu \mathrm{m}$. $\beta$-Conidia were unicellular, aseptate, hyaline, filiform, curved at one end, and 22.4-31.6 × 1.4-1.7 $\mu \mathrm{m}$ big (Fig. 6f).

Based on BLAST analyses of TEF1, ITS, and TUB sequences, $D$. eres isolates obtained from Austrian soybean seeds were highly homologous to $D$. eres which were isolated from different hosts including soybean in different countries (Table 2). In the alignments, the ITS, TUB, and TEF sequences for our $D$. eres isolates showed a few differences. According to the sequences, isolates DPC $\mathrm{HOH}_{10}$ and DPC $\mathrm{HOH}_{2} 7$ are identical and also the isolates DPC_HOH3 and DPC_HOH14 while DPC_HOH7 stands alone (Figs. 1, 2, and 4).

Diaporthe caulivora (Athow \& Caldwell) J.M. Santos, Vrandečić \& A.J.L. Phillips, Persoonia 27: 13 (2011).

Basionym: Diaporthe phaseolorum var. caulivora Athow \& Caldwell, Phytopathology 44: 323 (1954). 

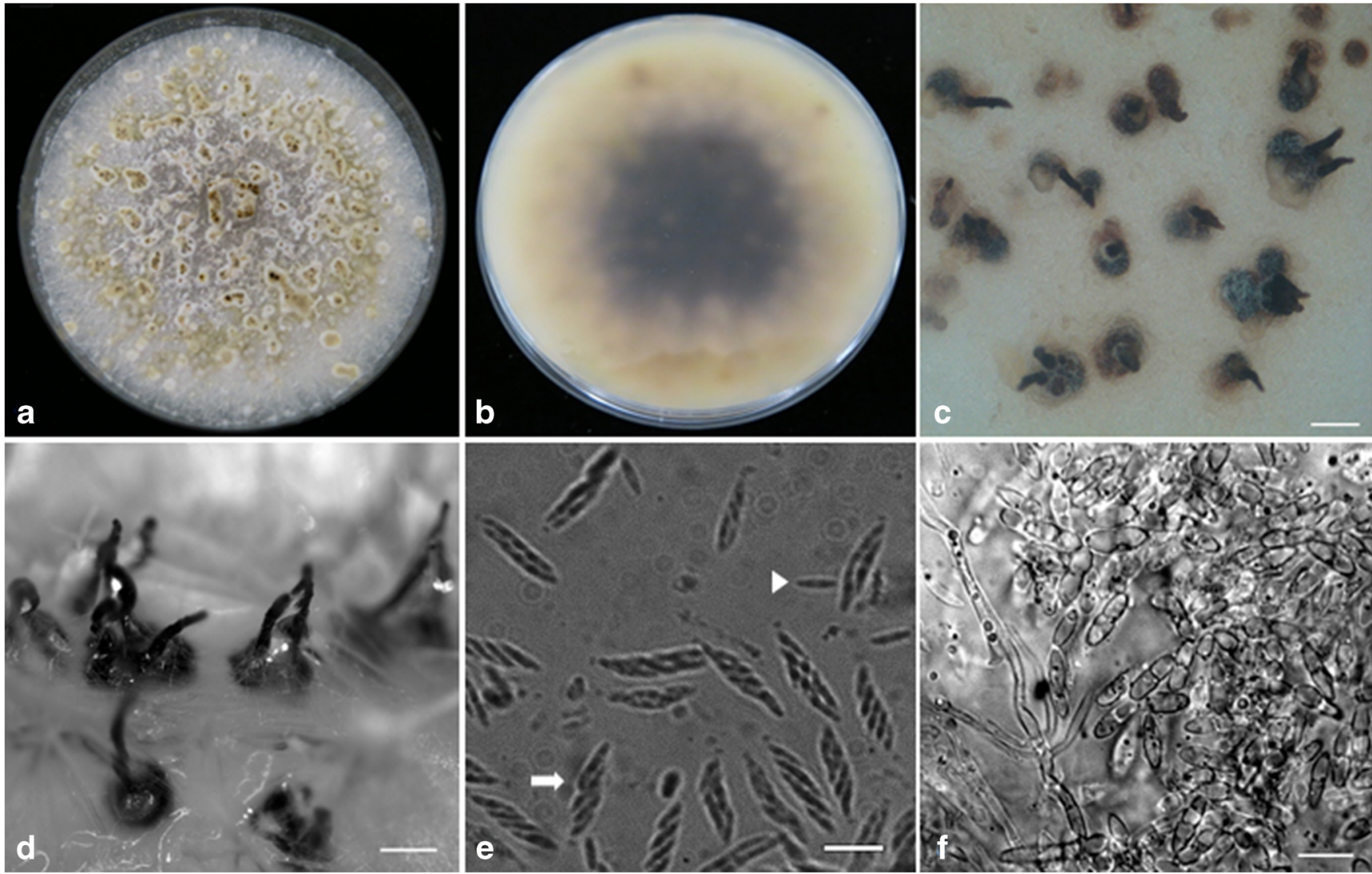

Fig. 7 Macro- and micrographs of D. caulivora (isolate $\mathrm{DPC} \mathrm{HOH} 2$ ). a Surface view of the cultures on APDA after 1 month. b Backside view of the cultures. $\mathbf{c}$ Perithecial necks on APDA after 2 months. $\mathbf{d}$ Perithecial

necks on soybean stem in culture. e Asci (arrow) and ascospores (arrow head). f Ascospores. Scale bars (c, d) $500 \mu \mathrm{m}$, (e) $20 \mu \mathrm{m}$, (f) $10 \mu \mathrm{m}$

Sequences from ex-type strains: ITS: HM347712, TEF1: HM347691, and TUB: KC344013.

D. caulivora (DPC_HOH2, DPC_HOH4) produced fluffy cultures on APDA initially appearing as white or whiteyellow and in older age yellow-ochre (Fig. 7a). The color on the back of the plate was light ochre to tan, light yellow, or yellow (Fig. 7b). Development of perithecia was observed on APDA plates (Fig. 7c) and on soybean stems placed on WA (Fig. 7d) after 2 months; this was the most distinguishing character for this species. The perithecia with black and straight necks formed in single or established in groups of 2-3 (Fig. 7c, d). Asci (30.6-43.0 $\times 7.0-9.5 \mu \mathrm{m})$ containing eight ascospores of ellipsoid shape, were enlarged in the middle and towards the vertices with obvious apical rings rounded (Fig. 7e). Ascospores $(8.3-11.0 \times 1.7-2.9 \mu \mathrm{m})$ were translucent, ellipsoidal to fusoid, septate, four guttules, 2-guttules per cell, central ones widest (Fig. 7f).

Based on BLAST analysis of the obtained TEF1, ITS, and TUB sequences, D. caulivora isolates were highly homologous to $D$. phaseolorum var. caulivora strains that were found on soybean in Serbia, Korea, and Croatia (Table 2). In the alignments, both isolates of $D$. caulivora were identical except in case of ITS where a few bases differed (Figs. 1, 2, 3, and 4).

Diaporthe novem J.M. Santos, Vrandečić \& A.J.L. Phillips, Persoonia 27: 14 (2011).

Anamorph: Phomopsis sp. 9 van Rensburg et al. Stud Mycol 55: 65 (2006).

Etymology: Latin for nine, the name by which this species has been known since 2006 (van Rensburg et al. 2006), namely Phomopsis sp. 9.

Sequences from ex-type strains: ITS: HM347710, HM347708, HM347709, TEF1: HM347693, HM347695, HM347696, and TUB: KC344123, KC344125.

D. novem (DPC_HOH8, DPC_HOH11, DPC_HOH15, and DPC_HOH16) on APDA gave white colonies. The central part of surface and back side had a translucent to ochreous color (Fig. 8a, b). These isolates reproduced asexually and they produced abundant, dense, yellow drops exuding from the pycnidia (with necks) (Fig. 8d), which contained abundant hyaline, unicellular, often biguttulate, ellipsoid, and long $\alpha$ conidia $(5.8-7.9 \times 1.8-2.3 \mu \mathrm{m})$ (Fig. $8 \mathrm{f})$. The $\alpha$-conidia of this species were longer than those of $D$. longicolla and $D$. eres. Colony description was similar to Phomopsis sp. CBS 117165. TEF1, ITS, and TUB sequences of $D$. novem isolates showed a high similarity to $D$. novem, Phomopsis sp. 9 and D. pseudolongicolla isolates which were found on soybean in Croatia and Serbia (Table 2). 

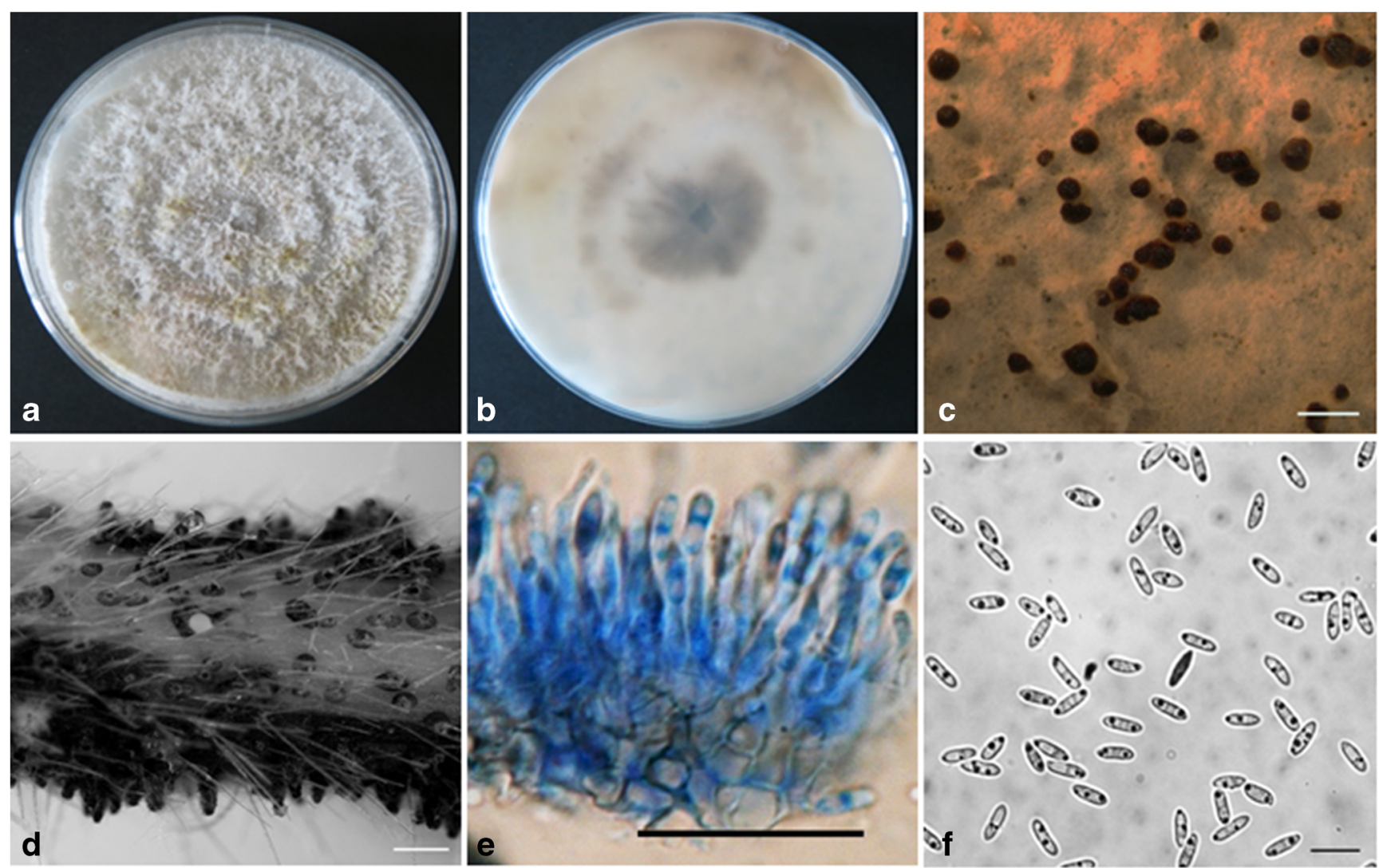

Fig. 8 Macro- and micrographs of D. novem (isolate DPC HOH16). a Surface view of the cultures on APDA after 1 month. $\mathbf{b}$ Backside view of the cultures. c Conidiomata on APDA. d Pycnidia on soybean stem in

Sequence wise, $D$. novem showed the biggest differences. While isolates DPC_HOH15 and DPC_HOH16 were identical, DPC_HOH8 showed some difference to the others in the TUB sequence. Interestingly, the isolate DPC_HOH11 in the ITS sequence was so different that in the phylogeny it was placed into a separate clade (Fig. 1). The ITS sequence of DPC_HOH11 had highest similarity to Phomopsis sp. (98\% identity) then $D$. pseudolongicolla (91\% identity) and only $90 \%$ identity to $D$. novem. The similarities in the other two genes are the reason why DPC_HOH11 is placed with $D$. novem in the combined tree (Fig. 4). According to the morphological characteristics, isolate DPC_HOH11 is classified as $D$. novem. Nevertheless, it has several mutations in the ITS that put it apart from other $D$. novem isolates.

\section{Pathogenicity of the Diaporthe isolates}

In our pathogenicity test, all 32 Diaporthe isolates were able to cause disease symptoms matching pod and stem blight disease on soybean plants (Fig. 9a, b). Discoloration of pods was observed on all the mature inoculated soybean plants and there were no significant differences between the Diaporthe isolates to cause pod blight (Fig. 10). Some differences were observed among the isolates for the appearance of black culture. e Conidiogenous cells and conidiophores. $\mathbf{f} \alpha$-conidia. Scale bars (c, d) $500 \mu \mathrm{m}$, (e) $20 \mu \mathrm{m}$, (f) $10 \mu \mathrm{m}$

pycnidia on soybean stems (Fig. 11). Here the highest level was caused by isolates of $D$. longicolla, particularly DPC_HOH32, DPC_HOH28, and DPC_HOH26. Isolates belonging to D. caulivora and D. eres did not form black pycnidia on stems of the plants. Only two isolates, DPC_HOH11 and DPC_HOH16, belonging to D. novem could produce a few pycnidia on stems of the inoculated plants.

\section{Discussion}

Due to the high degree of overlapping morphological characteristics among DPC species, delineation of these species is not possible based on morphology alone. Therefore, efforts have been made using molecular tools to distinguish among DPC species and clarify the phylogeny of these fungi (Baumgartner et al. 2013; Gomes et al. 2013; Udayanga et al. 2014a, 2014b). Also, accurate nomenclature of this group of fungi is crucial. Hence, following the Rossman recommendations (Rossman et al. 2015), to avoid competition in the use of two or more different names for this species complex which are typified by their sexual or asexual morphs, and also because of priority of the older generic name of 
Fig. 9 a Pod and stem blight symptoms on soybean plants caused by $D$. longicolla (isolate DPC_HOH28). b Black pycnidia on soybean stems caused by $D$. longicolla (isolate DPC_HOH28)

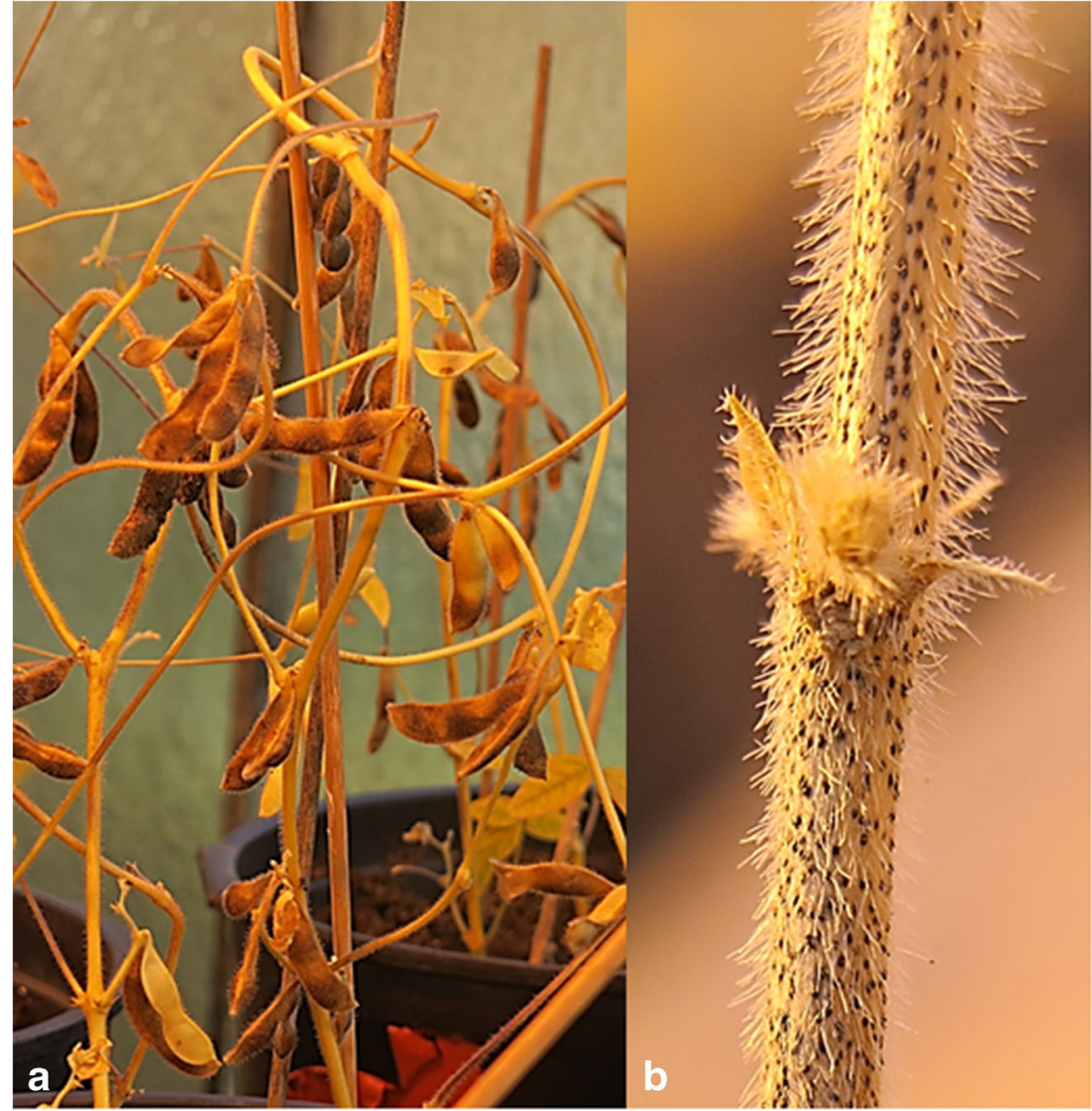

Diaporthe (1870) over Phomopsis (1905) (Santos and Phillips 2009), the name Diaporthe was used in the present study. Species of Diaporthe on central European soybean were studied based on morphological features which included their cultural characteristics on APDA, type of reproduction and characteristics of spores, and DNA sequence analyses using three genes (ITS, TEF1 and TUB). Combining the results from morphological and molecular identification allowed the alignment of the isolates into four different Diaporthe species, namely $D$. longicolla, $D$. caulivora, $D$. eres, and $D$. novem.

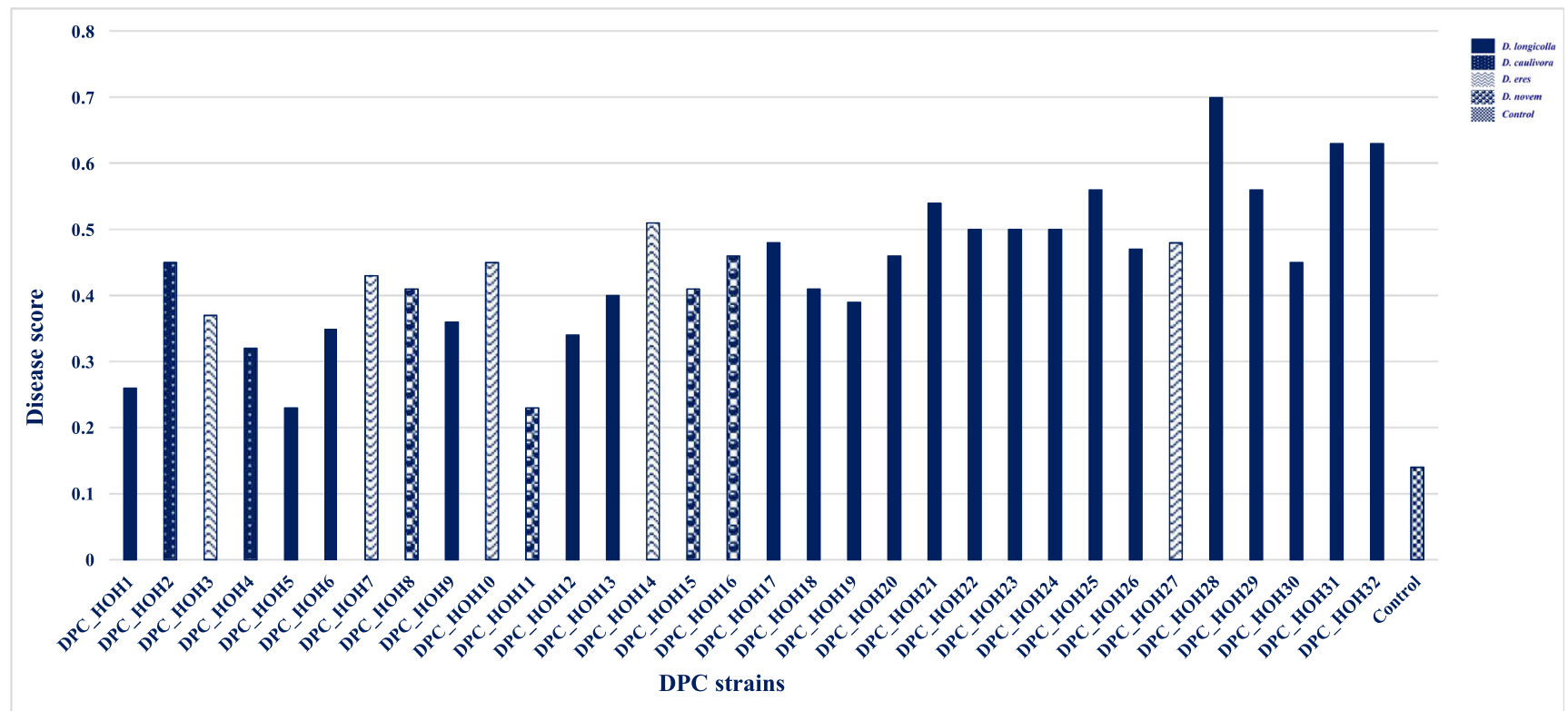

Fig. 10 Evaluation of pod blight disease on soybean plants which were inoculated by conidia suspension of the 32 Diaporthe isolates. Columns represent the average disease score based on four evaluations of nine plants each. The species of the different isolates are indicated by the column patterns 


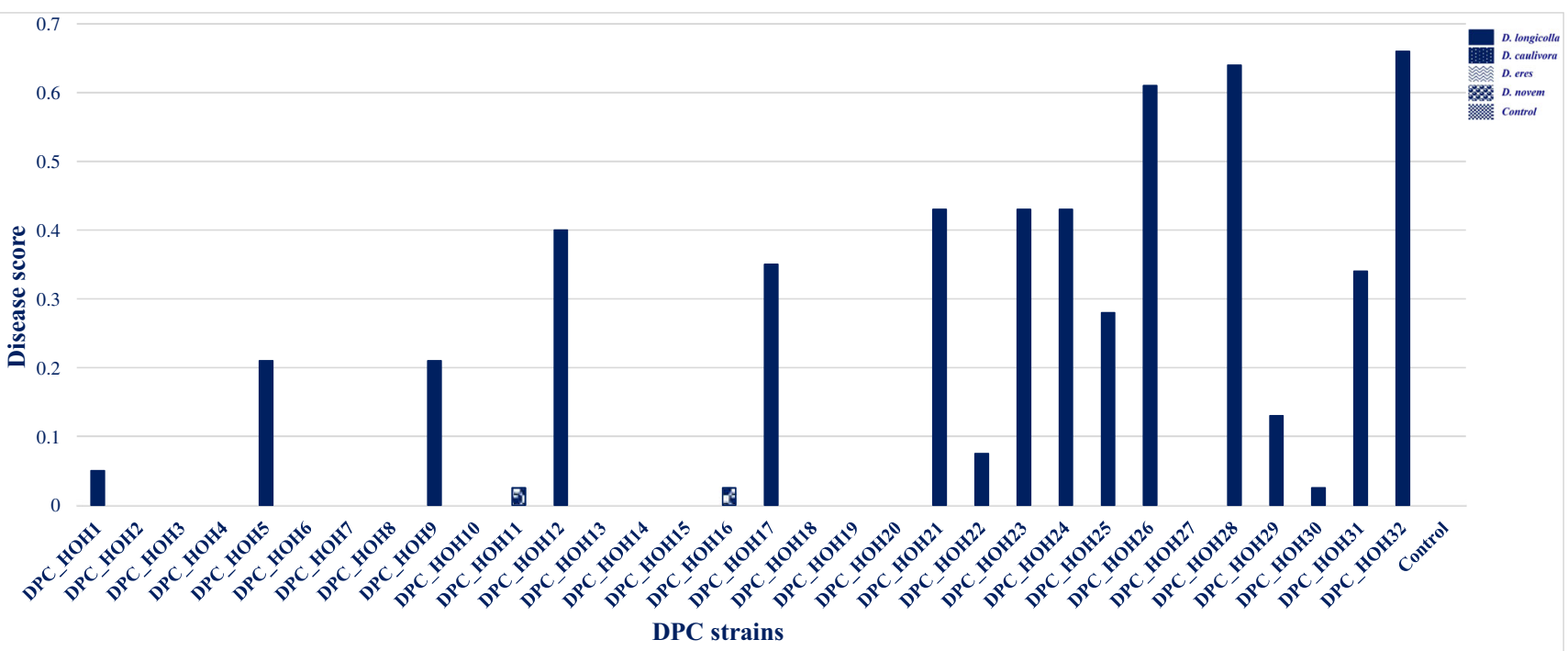

Fig. 11 Evaluation of accumulation of black pycnidia on soybean stems which were inoculated by conidia suspension of the 32 Diaporthe isolates. Columns represent the average disease score based on four evaluations of nine plants each. The species of the different isolates are indicated by the column patterns

our knowledge, $D$. eres identified in this study seems to be isolated from soybean seeds in Austria for the first time. Our D. eres isolates showed morphological characteristics (i.e., colony appearance, formation of pycnidia, absence of perithecia, existence of both $\alpha$-conidia and $\beta$-conidia, and conidia dimensions) similar to those of $D$. eres isolated from soybean seeds in Serbia. Furthermore, TEF1 and ITS sequences of the presented $D$. eres isolates were highly homologous to that found by Petrović et al. (2015).

D. caulivora did not reproduce asexually in this study. However, the same finding had been already reported in Argentina (Grijalba and Ridao 2012). Albeit it is also observed that $D$. caulivora can seldom produce pycnidia (Santos et al. 2011). The presence of pycnidia included $\alpha$ conidia and $\beta$-conidia in $D$. caulivora reported by Fernández and Hanlin (1996) and Kmetz et al. (1978) mentioned that formation of pycnidia was uncommon in $D$. caulivora that produced just $\beta$-conidia.

Our results showed discrepancies between the BLAST results for the TEF1 sequence, the TUB sequence, and the ITS sequence. While these discrepancies might have been due to inconsistent annotations in the NCBI database, the discrepancies we found in our phylogenies regarding isolate DPC_HOH11 must have natural reasons. For this isolate, the ITS sequence does give a completely separate clade in the phylogeny. This could be due to a special mutation event, changing several bases in the ITS region at the same time or to hybridization between $D$. novem and a different Diaporthe species that was not part of our study. However, the possibility for hybridization between Diaporthe species would be a highly plausible explanation for the overlapping morphologies of soybean was in Serbia (Petrović et al. 2015). According to 
the species that we described above and for the general difficulties in clearly resolving the species complex.

Acknowledgments We would like to express our sincere gratitude to Taifun-Tofu GmbH (Freiburg, Germany) for providing soybean seedlots, and to Barbara Kaufmann and Heike Popovitsch for technical assistance.

Funding information Open Access funding provided by Projekt DEAL. Financial support is provided by the Faculty of Agricultural Sciences and Food Security Center (FSC) of University of Hohenheim to the first author.

Open Access This article is licensed under a Creative Commons Attribution 4.0 International License, which permits use, sharing, adaptation, distribution and reproduction in any medium or format, as long as you give appropriate credit to the original author(s) and the source, provide a link to the Creative Commons licence, and indicate if changes were made. The images or other third party material in this article are included in the article's Creative Commons licence, unless indicated otherwise in a credit line to the material. If material is not included in the article's Creative Commons licence and your intended use is not permitted by statutory regulation or exceeds the permitted use, you will need to obtain permission directly from the copyright holder. To view a copy of this licence, visit http://creativecommons.org/licenses/by/4.0/.

\section{References}

Athow KL, Caldwell RM (1954) A comparative study of Diaporthe stem canker and pod stem blight of soybean. Phytopathology 44:319-325

Baird RE, Abney TS, Mullinix BG (2001) Fungi associated with pods and seeds during the R6 and R8 stages of four soybean cultivars in southwestern Indiana. Phytoprotection 82:1-11. https://doi.org/10. 7202/706210ar

Baumgartner K, Fujiyoshi PT, Travadon R, Castlebury LA, Wilcox WF, Rolshausen PE (2013) Characterization of species of Diaporthe from wood cankers of grape in eastern North American vineyards. Plant Dis 97:912-920. https://doi.org/10.1094/PDIS-04-12-0357RE

Carbone I, Kohn LM (1999) A method for designing primer sets for speciation studies in filamentous ascomycetes. Mycologia 91:553556

Choi YW, Hyde KD, Ho WH (1999) Single spore isolation of fungi. Fungal Divers 3:29-38

Costamilan LM, Yorinori JT, Almeida AMR, Seixas CDS, Binneck E, Araújo MR, Carbonari JA (2008) First report of Diaporthe phaseolorum var. caulivora infecting soybean plants in Brazil. Trop Plant Pathol 33:381-385. https://doi.org/10.1590/S198256762008000500007

Divilov K (2014) Taxonomy and biocontrol of Diaporthe sojae and screening for resistance to Phomopsis seed decay caused by an atypical Diaporthe sojae isolate using various assays. Dissertation, University of Illinois

Fernández FA, Hanlin RT (1996) Morphological and RAPD analyses of Diaporthe phaseolorum from soybean. Mycologia 88:425-440

Glass NL, Donaldson G (1995) Development of primer sets designed for use with PCR to amplify conserved genes from filamentous ascomycetes. Appl Environ Microbiol 61:1323-1330

Gomes RR, Glienke C, Videira SIR, Lombard L, Groenewald JZ, Crous PW (2013) Diaporthe: a genus of endophytic, saprobic and plant pathogenic fungi. Persoonia 31:1-41. https://doi.org/10.3767/ 003158513 X666844
Grijalba P, Ridao AC (2012) Survival of Diaporthe phaseolorum var. caulivora (causal agent of soybean stem canker) artificially inoculated in different crop residues. Trop Plant Pathol 37(4):271-274. https://doi.org/10.1590/S1982-56762012000400006

Hall TA (1999) BioEdit: a user-friendly biological sequence alignment editor and analysis program for Windows 95/98/NT. Nucleic Acids Symp Ser 41:95-98

Hobbs TW, Schmitthenner AF, Kuter GA (1985) A new Phomopsis species from soybean. Mycologia 77:535-544

Kmetz KT, Schmitthenner AF, Ellett CW (1978) Soybean seed decay: prevalence of infection and symptom expression caused by Phomopsis sp., Diaporthe phaseolorum var. sojae, and D. phaseolorum var. caulivora. Phytopathology 68:836-840. https:// doi.org/10.1094/Phyto-68-836

Kulik MM (1984) Symptomless infection, persistence, and production of pycnidia in host and non-host plants by Phomopsis batatae, Phomopsis phaseoli, and Phomopsis sojae, and the taxonomic implications. Mycologia 76(2):274-291

Kumar S, Stecher G, Li M, Knyaz C, Tamura K (2018) MEGA X: molecular evolutionary genetics analysis across computing platforms. Mol Biol Evol 35(6):1547-1549. https://doi.org/10.1093/molbev/ msy096

Lehman SG (1923) Pod and stem blight of soybean. Ann Mo Bot Gard 10:111-178

Liu D, Coloe S, Baird R, Pedersen J (2000) Rapid mini-preparation of fungal DNA for PCR. J Clin Microbiol 38(1):471

Mengistu A, Castlebury LA, Morel W, Ray JD, Smith JR (2014) Pathogenicity of Diaporthe spp. isolates recovered from soybean (Glycine max) seeds in Paraguay. Can J Plant Pathol 36(4):470 474. https://doi.org/10.1080/07060661.2014.966151

Morgan-Jones G (1989) The Diaporthe/Phomopsis complex: taxonomic considerations. In: Pascale A (ed) Proceedings of the world soybean research conference IV. Orientación Gráfica, Buenos Aires, pp 1699-1706

Morgen-Jones G (1985) The Diaporthe/Phomopsis complex of soybean: morphology. In: Proceedings of the conference on Diaporthel Phomopsis disease complex of soybean. United States Department of Agriculture, Beltsville, pp 1-7

Mostert L, Crous PW, Kang J, Phillips AJL (2001) Species of Phomopsis and a Libertella sp. occurring on grapevines with specific reference to South Africa: morphological, cultural, molecular and pathological characterization. Mycologia 93(1):146-167

Nevena M, Jelena V, Franić-Mihajlović D (1997) A comparative study of Diaporthe/Phomopsis fungi on soybean from two different regions of the world. Mycopathologia 139:107-113

Nitschke T (1870) Pyrenomycetes Germanici, vol 2. Eduard Trewendt, Breslau, p 245

Petrović K, Vidić M, Riccioni L, Đorđević V, Rajković D (2015) First report of Diaporthe eres species complex causing seed decay of soybean in Serbia. Plant Dis 99(8):1186. https://doi.org/10.1094/ PDIS-01-15-0056-PDN

Pioli RN, Morandi EN, Biasaro V (2001) First report of soybean stem canker caused by Diaporthe phaseolorum var. caulivora in Argentina. Plant Dis 85:95. https://doi.org/10.1094/PDIS.2001.85. $1.95 \mathrm{~B}$

Rayner RW (1970) A mycological colour chart. Commonwealth Mycological Institute, British Mycological Society, p 33

Rossman AY, Adams GC, Cannon PF, Castlebury LA, Crous PW, Gryzenhout M, Jaklitsch WM, Mejia LC, Stoykov D, Udayanga D, Voglmayr H, Walker DM (2015) Recommendations of generic names in Diaporthales competing for protection or use. IMA Fungus 6(1):145-154. https://doi.org/10.5598/imafungus.2015.06. 01.09

Santos JM, Phillips AJL (2009) Resolving the complex of Diaporthe (Phomopsis) species occurring on Foeniculum vulgare in Portugal. Fungal Divers 34:111-125 
Santos JM, Vrandečić K, Ćosić J, Duvnjak T, Phillips AJL (2011) Resolving the Diaporthe species occurring on soybean in Croatia. Persoonia 27:9-19. https://doi.org/10.3767/003158511X603719

Schoch CL, Seifert KA, Huhndorf S, Robert V, Spouge JL, Levesque CA, Chen W et al (2012) Nuclear ribosomal internal transcribed spacer (ITS) region as a universal DNA barcode marker for fungi. Proc Natl Acad Sci U S A 109:6241-6246. https://doi.org/10.1073/pnas. 1117018109

Sinclair JB (1992) Discoloration of soybean seeds in an indicator of quality. Plant Dis 76:1087-1091

Sinclair JB (1993) Phomopsis seed decay of soybeans - a prototype for studying seed disease. Plant Dis 77(4):329-334

Sinclair JB, Backman PA (1989) Compendium of soybean diseases, 3rd edn. American Phytopathological Society Press, Saint Paul, p 106

Sun S, Kim MY, Chaisan T, Lee YW, Van K, Lee SH (2013) Phomopsis (Diaporthe) species as the cause of soybean seed decay in Korea. J Phytopathol 161:131-134. https://doi.org/10.1111/jph.12034

Tamura K, Nei M (1993) Estimation of the number of nucleotide substitutions in the control region of mitochondrial DNA in humans and chimpanzees. Mol Biol Evol 10(3):512-526

Tamura K, Nei M, Kumar S (2004) Prospects for inferring very large phylogenies by using the neighbor-joining method. Proc Natl Acad Sci U S A 101(30):11030-11035 www.pnas.org/cgi/doi/10. 1073/pnas.0404206101

Thompson SM, Tan YP, Young AJ, Neate SM, Aitken EAB, Shivas RG (2011) Stem cankers on sunflower (Helianthus annuus) in Australia reveal a complex of pathogenic Diaporthe (Phomopsis) species. Persoonia 27:80-89. https://doi.org/10.3767/003158511X617110

Udayanga D, Liu X, Crous PW, McKenzie EHC, Chukeatirote E, Hyde KD (2012) A multi-locus phylogenetic evaluation of Diaporthe (Phomopsis). Fungal Divers 56:157-171. https://doi.org/10.1007/ s13225-012-0190-9

Udayanga D, Castlebury LA, Rossman AY, Chukeatirote E, Hyde KD (2014a) Insights into the genus Diaporthe: phylogenetic species delimitation in the D. eres species complex. Fungal Divers 67: 203-229. https://doi.org/10.1007/s13225-014-0297-2

Udayanga D, Castlebury LA, Rossman AY, Hyde KD (2014b) Species limits in Diaporthe: molecular re-assessment of D. citri, D. cytosporella, D. foeniculina and D. rudis. Persoonia 32:83-101. https://doi.org/10.3767/003158514X679984

van der Aa HA, Noordeloos ME, Gruyter J (1990) Species concepts in some larger genera of the Coelomycetes. Stud Mycol 32:3-19

van Niekerk JM, Groenewald JZ, Farr DF, Fourie PH, Halleen F, Crous PW (2005) Reassessment of Phomopsis species on grapevines. Australas Plant Pathol 34:27-39. https://doi.org/10.1071/AP04072

van Rensburg JCJ, Lamprecht SC, Groenewald JZ, Castlebury LA, Crous PW (2006) Characterisation of Phomopsis spp. associated with dieback of rooibos (Aspalathus linearis) in South Africa. Stud Mycol 55:65-74. https://doi.org/10.3114/sim.55.1.65

Walcott RR (2014) Acidified PDA method for the detection of Phomopsis complex on Glycine max. In: International rules for seed testing. International Seed Testing Association (ISTA), Bassersdorf, pp 7-016

White TJ, Bruns T, Lee J, Taylor J (1990) Amplification and direct sequencing of fungal ribosomal RNA genes for phylogenetics. In: Innis MA, Gelfand DH, Sninsky JJ, White TJ (eds) PCR protocols: a guide to methods and applications. Academic, New York, pp 315322

Zhang AW, Riccioni L, Pedersen WL, Kollipara KP, Hartman GL (1998) Molecular identification and phylogenetic grouping of Diaporthe phaseolorum and Phomopsis longicolla isolates from soybean. Phytopathology 88(12):1306-1314. https://doi.org/10.1094/ PHYTO.1998.88.12.1306

Publisher's note Springer Nature remains neutral with regard to jurisdictional claims in published maps and institutional affiliations. 